Kovács Atrila hunim@freemail.hu

\title{
A Kazár Kaganátus egy népe: a burtászok
}

\author{
-A Tribe of the Khazar Khaganate: the Burtas -
}

\begin{abstract}
If we consider the written sources about the Burtas, it can be concluded that the Muslim writers provide the most detailed and precise descriptions. The origin of the Burtas is widely disputed; some researchers suggest that they are Turkish, while others support the theory of their Iranian origin. However, the majority of international scientists consider the Burtas as the ancestors of a Finno-Ugric people, the Mordvins, drawing this conclusion from the Burtas' name. According to the popular explanation, Burtas and Merdas ethnic names occurring in different written sources denote the same people, since the localization and lifestyles are identical in the descriptions. Written accounts also report thatthe Burtas used a complex farming system involving both agriculture and large-scale livestock breeding. They dwelled west from the Volga and their territory may have stretched to the river Don. Thus, it is a fact that they lived on the wooded steppe. If we compare Latin, Hebrew and Russian sources with the Muslims, it becomes obvious that the Burtas tribe is not identical with the Mordvins, meaning that the Burtas/Merdas identification is false as well. The endonym of the Mordvins supports this hypothesis. The Mordvins do not use the name Mordvin for themselves; it is a Russian loanword. They call themselves Moksa and Erä. Consequently, the term Burtas cannot be connected to the endonym of the Mordvins. Moreover, I have newly discovered a Russian source, a list of the taxpayers of Vladimir prince of the Rus where the Burtas and Mordvins are handled as separate ethnic groups. This means that the Burtas were an independent tribe living in the region between the Middle Volga and the Don; their neighbourswere the Khazars in the South and the Volga Bulgars in the North. The Burtas were subjected firstly by the Khazars until the end of the 10th century, then by the Volga Bulgars and later by the Rus. After the Mongolian attack in 1230 s, they became dependent of the Mongolians and gradually disappeared from the written sources.
\end{abstract}

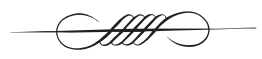

A burtászok a Kazár Kaganátus fontos részét alkották, akárcsak a magyarok, eredetük teljesen bizonytalan, és a nemzetközi szakirodalom alapvetően a ma élö mordvinok őseinek gondolja öket. A burtászok, elhelyezkedésüket tekintve, Kelet-Európa két legfontosabb vízi útja, a Don- és a Volga között laktak. E két folyam mentén zajlott az észak-déli kereskedelem nagy része, amit nagyban elősegített e két folyók hajózhatósága. Ráadásul a kelet-nyugati kereskedelmi utak is érintették szállásterületeiket. Jelentős geopolitikai helyzetüknél fogva, szomszédjaik igyekeztek fennhatóságuk alá vonni öket. Ennek köszönhetően, hol a Kazár Birodalom, hol a volgai bolgárok, majd a ruszok, és végül a mongolok uralma alatt is éltek. Így, kulturálisan sokféle behatás érte 
őket. Megismerkedhettek a judaizmussal, az iszlámmal, és a kereszténységgel. Elhelyezkedésüket tekintve pedig, közvetlen szomszédjai lehettek őseinknek, ami hatással lehetett mindkét nép nyelvére, gazdaságára, kultúrájára, és etnikai arculatára. Ugyanakkor fontos szerepet játszhattak a közelükben elhelyezkedő erdővidéki finnugor népek történelmében.

A vizsgált korszak, két részre bontható. Az egyik az időszámításunk után a 9. századtól a Kazár Birodalom összeomlásáig, azaz 965-ig tart. A másik ettől egészen a mongol hódításig, vagyis 1237-ig. Az első időintervallum azért érdekes, mert a kor egyik nagyhatalma a Kazár Kaganátus volt. Ez egy nomád birodalom volt, de a közhiedelemmel ellentétben nem csak nomád népek éltek együtt keretein belül. Adófizetői voltak erdőlakó finnugor és szláv népek. Továbbá hadi kontingens kiállítására kötelezett katonai segédnépek, mint például a magyarok és az alább bővebben tárgyalandó burtászok. A korban jelentős hadi potenciálja mellett kiemelkedő kereskedelmi forgalmat lebonyolító hatalomnak tekinthetjük a Kazár Birodalmat. Nyilvánvaló, hogy a hadjárat zsákmányaiból a segédnépek is részesültek, és a kereskedelmi haszonból is juthatott a birodalom keretein belül élö, a kereskedelemben aktívan részt vevő népcsoportoknak. Természetesen ezek a népek egymással is kereskedtek, és különböző gyakran vérségi kötelékeket is létesítettek egymással. Így korántsem mindegy, hogy a fent említett burtászok kikkel voltak közvetlenül határosak a birodalmon belül. Ez a magyarság etnogenezise szempontjából sem mellékes, hiszen a burtászok délkeleti szomszédjai voltak, egészen a 9. század végéig. A burtászok területe éghajlati szempontból nagyon előnyösnek mondható. A csapadékmennyiség nagyobb mennyiségü volt és egyenletesebb eloszlást mutatott, mint a tölük délre elhelyezkedő füves sztyeppén. Területük nagy része az erdős sztyeppe területére esett. Természetesen nem kizárólagos jelleggel. Északon az Alatir folyó vidékén belenyúlt az erdővidékbe, míg délen a Vorona és a Medvegyica folyó felső folyásánál már a füves sztyeppe jellemezte területüket. Ennek megfelelően a gazdálkodásuk is a környezeti feltételek adta lehetőségekhez idomult. Fenn áll a kérdés, hogy a burtászok milyen életmódot folytattak? Nomádok voltak-e vagy inkább letelepült népesség? Mennyire volt egységes ez a nép életmódjában és kultúrájában? Milyen etnikai elemekből épülhetett fel és milyen nyelven beszélt? Mit szívott fel a birodalom kulturális közegéből? Ezekre a kérdésekre is kerestem a választ munkám megírásakor. Természetesen nem lehet minden kérdést kielégítően megválaszolni. Szakdolgozatom egy rövidített és némileg átírt részéből született ez a tanulmány, amely alapvetően arra törekszik, hogy a tudományos eredményeket némileg közérthetőbb formában ismertesse a szélesebb olvasóközönséggel.

Amit a burtászokról tudunk, az elsődlegesen a forrásokból származik. A tanulmány felépítését tekintve először a burtászokról szóló muszlim források közül idézem a jelentősebbeket. A muszlim szerzők jó része, mint kereskedő, követ járt a burtászok között, vagy kereskedőktől szerezte információit. Így a ránk maradt müveik alapvetően hitelesnek tekinthetők. A kortárs muszlim források döntő fontosságúak a burtászokra vonatkozó híradások között. Ezen források mintegy öt évszázadot fognak át. Természetesen a források információi időben nem arányosan oszlanak meg. Az írott kútfök csak a 10. és a 13. században tesznek említést az általam vizsgált népről. A 1112. század folyamán azonban semmiféle írásos feljegyzés nem született a burtászokról. Ezeknek az időbeli hiátusoknak a kitöltése érdekében - valamint a burtászok történetének tökéletesebb megismerése céljából - a muszlim mellett, orosz és latin nyelvű forrásokat is felhasználok. Továbbá meg kell még említenünk a József kazár kagánhoz köthető levél héber nyelvü szövegét is. Kiemelten fontos még, az orosz nyelvü forrás, amelyek értékes információt tartalmaz a burtászokra nézve. 


\section{Források}

A muszlim források a vonatkozó korszakra jóval tájékozottabbak voltak a többi kortárs kútfőnél. ${ }^{1}$ A lejegyzett, általában pontos információk sokrétüek, részletesen kitérnek a vizsgált térség éghajlatára, útvonalhálózatára, az ott élő népek kereskedelmére, egymás közti kapcsolatára, életmódjukra, társadalmukra, államszervezetükre és szokásaikra. A muszlim utazók és kereskedők kémek is voltak egyben, valamint az iszlám hit terjesztését is felvállalták, ha módjukban állt. ${ }^{2} \mathrm{Az}$ információértékre tekintettel, a muszlim forrásokból többet idézek, nem elhanyagolva a többi forráscsoport reprezentatív bemutatását. Elsőként al- Dzsajháni hagyomány egyik legjelentősebb szerzőjének, Ibn Rusztának a vonatkozó részét ismertetem:

„Burdās földje a hazar ${ }^{3}$ s bulkār ${ }^{4}$ között fekszik; köztüks a kazárok között tizenöt napi távolság van. A kazár királynak engedelmeskednek. Tízezer lovas vonul közülük harcba. Fönökök, a ki öket rendben tartaná s akinek itélete mérvadó volna közöttük, nincsen, hanem minden szállásukban van egy-két vén; pörös ügyeiket, ha ilyenek elöadják magukat közöttük, ezek elé viszik, de alapjában a kazár király hódoltsága alatt állnak. Földjük kiterjedt; erdökben laknak. A bulkār s a bağānākīya $a^{5}$ ellen támadásokat intéznek. Kitartók és erélyesek. Vallásuk a guzzīya $a^{6}$ valláshoz hasonlit. Kellemes arcuk, tekintetük és testük van. Ha valamelyikük részéröl más ellen támadás vagy igazságtalanság történt, avagy az illető sebet ejt rajta, vagy megszúrta, békés megegyezés addig nem jöhet létre közöttük, amíg a sebesült a bosszúját ki nem töltötte. Ha egy lány közülük felserdül, az engedelmességet apjának felmondva azt a férfit szemeli ki magának, akit akar, míg végre a kérő (a lány) apjához megy, megkéri a kezét és feleségül veszi töle, ha ugyan (a lány) akarja. Vannak tevéik, marháik és sok mézük. Vagyonuk java részét menyétbőrök képezik. Kétféle fajtájuk van: az egyik a halottakat elégeti, a másik eltemeti. A föld egyik síkságát lakják, erdöik fájának legnagyobb része hilinğ․ Vannak szántóföldjeik is. vagyonuk java részét méz, menyétbőrök és szörmék képezik. Országuk kiterjedése hosszában és széltében tizenkét nap.” (Kмоsкó 1997. 205-206.)

A következőkben al-Isztahri művét mutatom be, amely az al-Balhi féle hagyomány folytatója: „Ami az Atil ${ }^{8}$ folyót illeti, az értesüléseim szerint a Hirhīz $z^{9}$ közelében ered és a Kimakīya ${ }^{10}$ s a Gंuzzīya között elterülö vidéken átfolyik s a Kīmākīya és Ġuzzīya között határt képez. Utána nyugati irányban halad bulgar hátán, majd visszafordulva a kelettel szomszédos vidékek felé veszi útját, míg végre ar-Rūs-t átszelve Bulḡār, majd Burtās mentén halad el míglen a Kazár tengerbe szakad. ...Burtās, ök egy nemzet, akik a kazárokkal határosak; köztük és a kazárok között más nemzet nincs. Ezek az Atil völgye mentén szanaszét lakó nép. Burtās egyben vidéknek a neve,

\footnotetext{
${ }^{1}$ A legkorábbi írásos források arab és perzsa szerzőktől maradtak ránk,melyeket összefoglalóan muszlim forrásoknak nevezni.

2 „A szeldzsuk vezír Nizám al-Mulk az 1091-ben összeállított Szijászetnáméban, azaz A politika könyve címü müvében egy külön fejezet foglalkozik a kémekkel és azok feladataival. Ebben áll a következő passzus: „Mindenütt állandóan kémeknek kell járniuk mint kereskedők, utazók, szúfik, kuruzslók és koldusok. Mindenről, amit hallanak, tudósítaniuk kell, hogy semmi fontos ne maradjon ismeretlen, és az új eseményekre még időben a megfelelő ellenintézkedést foganatosítani lehessen..." Ezenkívül, még jelentös propaganda tevékenységet is kifejthettek. GöcKenjan 2001. 58-59.

3 A muszlim forrásokban a kazárokat jelenti.

${ }^{4}$ Itt a volgai bolgárokra utal a megnevezés.

${ }^{5}$ A muszlim források így nevezik a besenyöket.

${ }^{6}$ A muszlim forrásokban ez az úzok megnevezése.

7 A megnevezés tartalma ingadozott ugyan, de az esetek döntö többségében nyírfára utal.

8 A Volga folyó megnevezése.

9 Értve alattuk a kirgizeket.
} 
úgy mint ar-Rūs s al- $\underline{H} a z a r$, ellenben as-Sarīr birodalomnak a neve, nem pedig városnak, vagy embernek. ... A burtās szó vidék neve. Lakóinak faházaik vannak; szanaszéjjel szóródva laknak. ... Bulgāar nyelve olyan, mint a kazárok nyelve; burtās nyelve azonban más, hasonló képen a rus ${ }^{11}$ nyelve is más, mint a kazár s a burtās. ... Atiltól Burtās határának kezdetéig húsz, Burtās határának kezdetétöl a végéig mintegy tizenöt nap van. Burtās földjétöl a Bağanāk-ig mintegy tíz állomás" (Kмоsкó 2000. 29-32.)

Ibn Hauqál (ő szintén az al-Balhi-féle hagyomány követője), művében a következők szerepelnek: „Burtās a kazárokkal szomszédos nemzetek csoportja. Köztük s a kazárok között más nép nincsen. Oly nép ők, amely az Ātil völgye mentén szanaszéjjel lakik. Burtās egy vidéknek is a neve, úgy mint ar-rūs s al-hazar; viszont as-Sarīr birodalomnak vagy vidéknek a neve, nem pedig embereknek vagy törzseknek....Burtās vidéknek a neve; lakóinak faházai vannak; szanaszéjjel elszórva laknak nagy számuk és erejük miatt....A Bulgār-ok nyelve olyan, mint a kazárok nyelve; burtās nyelve más; hasonlóképpen a rūs nyelve más mint a kazárok és burtās nyelve." (Kмоsкó 2000. 78-80.)

Al-Bakri a következőket írja: „Ami a furdās (burdās) országát illeti, az a kazár s a bulkān (bulkār) között terül el. Közte s a kazárok országa között tizenöt napi járóút van. A bulkān s a bağānākīya ellen háborút viselnek. Vallásuk a ġuzzīya vallásához hasonlít. Tágas, sík földjük és sok árujuk van. Országuk hosszúságban és szélességben egyés fél járóföldre terjed. Számuk mintegy tízezer lovas. Fáik legnagyobb része a hilinğ. Vagyonuk java részét méz és menyét szörme képezi. Sok gulyájuk, juhnyájuk és kiterjedt szántóföldjeik vannak. Közülük az egyik csoport elégeti elesetteiket, mások eltemetik. Ha egy leány felserdül, apjának nincsen többé hatalma felette; a férfiak közül azt választja ki magának, akit akar.” (Кмоsкó 2000. 255.)

A héber nyelvü forrásunk József kazár kagán levele a következő: „Amit országunk kiterjedésével, szélességével és hosszúságával kapcsolatban kérdeztél. A Gargan-(Grg’n) tengerhez (Kaszpitenger) közeli folyó partján fekszik, kelet felé, négy hónapnyi járóföldre(tudatom veled, hogy az Atil('tl) folyó mellett lakom, a Gargan-tenger szélén, e folyóforrása keletfelé van, négy hónapnyi járóföldre). A folyó mellett sok nagy és számtalan nép él, falvak, városok és erödített helyek, kilenc nép, számtalan sokan vannak, mind nekem fizetnek adót (A folyó mellett sok nép falvakban és részben nyílt, részben megerösített városokban lakik. Ezek neve: Burtasz (Burts), Bulgar (bulgr), Szuvar(Su'r), Ariszu('rysu), Cermisz(Crmys), Venentit(Vnntyt), Szuvar(Suur), Clavijun(Cluyun), mindegyik igen nagy, számtalan sokan vannak, és nekem fizetnek adót)" (SHLOмо-Koмoróczy 2003. 100.; КонN $1990^{2}$. 39.)

Az Ének oroszföld pusztulásáról címü munka a következőket tartalmazza:

„Egészen a magyarok földjéig, polyákok és csehek országáig; csehektől a vjatvjákokig; vjatvjágoktól litvánok és németek földjéig; németektöl karélokig; karéloktól Usztyug városáig, hol a pogány tojmaiak laknak, és a Fehér-tengeren túl; a tengertöl a bolgárokig; bolgároktól burtaszok földjéig; burtaszoktól cseremiszekig; cseremiszektől a mordvinok földjéig az Úr mindent keresztény népünk uralmába hajta, minden országot Vszevolod nagyfejedelem akaratának rendele alá; és apjának, Jurijnak, Kijev fejedelmének, nagyapjának Vlagyimir Monomahnak, kinek nevével a polovecek apró gyermekeiket riogatták, a litvánok pedig nem merészkednek elö mocsaraikból; a magyarok köböl emelt városikat vaskapukkal erösíték meg, hogy a nagy Vlagyimir ellenük ne

${ }^{10}$ E nép itt a kimekeket jelenti, akiket később a kunok egyik csoportjával lehet azonosítani.

${ }^{11}$ Itt a ruszokról van szó, akik Skandináv eredetűek, és az erdővidék szlávjait alávetve szervezték meg birodalmuk, később összeolvadván velük közösen alkották az oroszok elődeit. 
vonuljon. A svédek pedig igen örvendezének, hogy a kék tenger megett a távolban lehetnek; a burtaszok meg cseremiszek, udmurtok és mordvinok erdei mézzel adóztak volt a nagy Vlagyimir fejedelemnek, és Bizánci Manuél is félelmében gazdag ajándékokat küldött volt néki, hogy Vlagyimir nagyfejedelem Bizánc városát ne vegye el töle” (IGLÓI-MisLEy 1979. 83.)

Utolsó forrásunk Rubruk útleírása 1255-ből:

„A Donon túl elterülő vidék gyönyörü szép, folyókban, erdőkben gazdag. Északon óriási erdöségek fekszenek, hol kétféle nép lakik: egyik a moksa(mordvin), amely semmiféle törvényt nem követ és teljesen pogány. Városaik nincsenek, erdei kunyhókban laknak. Urukés embereik jó része Németországban lelte halálát, a tatárok ugyanis egészen Németország végeihez hajtották őket, miért is nagy tiszteletben tartják a németeket, és remélik, hogy öáltaluk fognak megszabadulni a tatárok jármától. Ha egy kereskedö érkezik hozzájuk, az, akinél elöször megszáll, köteles öt ellátni mindaddig, amíg közöttük óhajt maradni. Ha valaki a más feleségével hál, amaz nem törödik vele, legfeljebb ha a szeme láttára történik, tehát nem féltékenyek. Igen sok disznót tartanak, bövelkednek mézben, méhviaszban, értékes szörmékben és sólymokban. Öutánuk következnek azok, akiket merdásznak mondanak, a latinok meg merdinisnek hívnak; ezek mohamedánok. Mögöttükfolyik az Etil, a legnagyobb folyó, amit valaha is láttam. Északról jön Nagy-Bolgárországból, és délnek tart, ...”. (GYÖRFFY 1986. 139.)

\section{A burtász név problémája}

Fölmerül egyrészt az a kérdés, mi az oka a forrásokban szereplő névváltozatoknak (burdās, burtās, burādās, furtās stb). Másrészt, hogy miért kapcsolják össze a burtász népnevet a mordvin népnévvel. ${ }^{12}$ Lehet, hogy a különböző alakok a különféle anyanyelvű tolmácsok kiejtését tükrözik. Ez nem elképzelhetetlen, ugyanis a Don-Volga vidéken éltek iráni nyelvű alánok, különböző török és szláv nyelvű népek. Lehetséges, hogy az arab és perzsa utazókértették más és másképpen ugyanazt a szót. Az eltérő olvasatok visszavezethetők az arab és perzsa írás- és hangrendszer sajátosságaira is. A muszlim földrajzi irodalomban a két alaplak a burdās vagy a burțās mellett megjelenik még a burā $\underline{d} a \bar{s}$ is. Valószínüsíthető, hogy a burdās vagy a burț̄ās alak volt az eredeti, ugyanis az arab nyelvü munkákban a szó alakja ebben a formában van meg. ${ }^{13}$ Ez a népnév a perzsa hangtani sajátosságok miatt burdās-ként jelenik meg a perzsa anyanyelvü muszlim íróknál. ${ }^{14}$ Ezt az elgondolást erősíti az-az ismeretünk is, miszerint az arab és perzsa szerzők nemcsak hogy ismerték egymás munkáit, hanem előszeretettel merítettek is azokból. Ráadásul a latin nyelvü munkákban -d-vel írják a népnevet, míg az orosz (burtas, brutas) és héber nyelvü munkában -t-vel szerepelnek. További kérdés, hogy a burtász népnév egy nép, vagy pedig egy adott terület neve. Mivel nem fordul elő máshogy, bizonyos, hogy a népről kapta a terület a nevét és nem fordítva.

A burtász népnévvel kapcsolatban a szakirodalom több elméletet is ismer. A legvalószínübb, hogy a burtász népnév írásának ingadozása eredményezte azt, hogy a bizonytalannak vélt népnévből minden kutató, az elméletének leginkább megfelelő névalakot használta. Ezek közül a

12 Például Hansgerd Göckenjan.

${ }^{13}$ Lásd al-Isztahri vagy al-Bakri munkáját (Кмозкó 2000).

${ }^{14}$ Jó példa erre Ibn Ruszta, aki perzsa anyanyelvü, de arabul írta munkáját, és ez leginkább a nép és személynevek írásánál lényeges. 
legnépszerűbb elmélet az, amely azt mondja, hogy a burdász az eredeti verzió. Ezt erősítené az a tény, hogy a forrásokban szereplö burdász név nagyon közel áll a mordvin népnévhez, amely a latin forrásokban szerepel. Így aztán a burdász-merdász névhasonlítás is alapul szolgált e két nép összekapcsolásához.

Az orosz őskrónikában mordva formában bukkan föl a népnév. A név eredetére nézve van olyan elmélet, amely szerint a mort 'ember' és a - $v a$ 'víz' zürjén eredetü összetételekből áll. ${ }^{15}$ Így a szó jelentése „vízi nép” lenne. A zürjén nyelvtani sajátosságok miatt azonban ez az összetétel egy "népvíz" értelmezést adna, ezért ez a megoldás elvethető. A Zsirai Miklós munkája Tomaschek elméletét is idézi, amely szerint: a szóösszetétel iráni eredetű, és a mort- $\chi y w a ̂$ 'emberevő' jelentéssel bír. Ez meggyőző lenne, ha nem tudnánk, hogy a szó eredeti alakja mord, a mordva, tehát a - $v$-s alak csak másodlagos fejlemény. Ez a - $v$-s forma pedig nyilvánvaló, hogy az oroszban jött létre. ${ }^{16}$ A fö probléma viszont az, hogy a mordvinok magukat sohasem hívták mordvának, mordvinnak. Önelnevezésként ez náluk ismeretlen, helyette az erzä és a moksa elnevezést használják. E két elnevezés eredetét pedig máig nem sikerült tisztázni (Zsırai 1937. 259-261).

Minorsky a burtászok nevéről külön nem értekezik, de feltételezi, hogy a Volgától nyugatra élő mordvinokkal azonosak. Ezen véleményét egy lábjegyzetben közli, amelyben Marquartot és Markovot idézi. Az általuk írottak alapján jut arra, hogy a burtászok neve iráni eredetü, és a burtászok a Volga középső folyásától délre éltek (MINORSKY 1937. 462-467).

A népnevekkel kapcsolatban sikerült egy nagyon sajátos logikai rendszert felismerni. $\mathrm{Z}$. V. Togan szerint, a burtászokat, a bolgárokat, és más középső Volga vidékén élő népeket șaqālibanak nevezték (Togan 1939. 305.). Amiből az szürhető le, hogy a muszlim szerzők ezeket az északon élő, nagyon távoli népeket egy gyüjtőnév alatt hozzák. ${ }^{17}$ Györffy véleménye az, hogy a merdász és a burtász név azonos, és a burtász népnév eredetileg a mordvinok egyik csoportját jelölte, mégpedig az erzäk. Szerinte a burtász elnevezés a finnugor nyelvü, de mohamedán vallású mordvinokat jelölte (GYöRfFY 1948. 72-73.). Minorsky 1958-ban írt munkájában elfogadja Togan fentebbi érvelését, azzal a megjegyzéssel, hogy ugyanakkor, a volgai bulgároknak, és a burtászoknak saját nevük volt (MiNORSKy 1958. 109-149.).

Zahoder egyet ért Szmirnovval, aki szerint a burtász elnevezés nem lehet iráni eredetü, ugyanis véleménye szerint a név a különböző török nyelvekkből jobban megfejthető. Ugyanígy elveti a szónak, a finn purdas 'híd' alakból származtatását. Egyúttal felhívja a figyelmet a hasonló hangzású török törzsnevekre. Szerinte ugyanúgy, mint a kelet-európai oguzok esetében - amely helyett a bizánci források az úz elnevezést, az orosz források a tork alakot, és az egyes muszlim írók a türkmén formát használják - a burtász szó is nem csak népet, hanem dinasztiát, hatalmon lévő törzset, vagy nemzetséget is jelölt. Megemlíti még, hogy így jött létre a Csagatáj és a Nogáj név is. Szerinte a burtászok katonai segédnép jellegéből adódóan nagy távolságokat járhattak be, ezért nevükkel sok helyen találkozhatunk. Így fordulhattak elő a Volga középső folyásának vidékén fellelhető toponímiákban. (ZAHODER 1962.230-252.). Zahoder munkája alapos, de azon érve, miszerint a csecsen nyelvben fennmaradtak burtász szavak, teljesen tarthatatlan, hiszen azt sem tudjuk teljes pontossággal megállapítani, hogy milyen nyelven beszéltek. Ráadásul saját maguk által készített írásos emlékeik egyáltalán nem maradtak fönn.

${ }^{15} \mathrm{Ez}$ az elmélet Castren ötleteként tünik föl a könyvben (Zsirai 1937. 259).

${ }^{16}$ Hasonló példa az oroszban tyky-tykva 'tök', és Tity > Titva (a folyó neve) (Zsirai 1937. 260.).

${ }^{17}$ A muszlimok nem voltak teljesen tisztában a nem szláv kelet-európai népekkel, így gyakran előfordul, hogy a șaqāliba nevet használják rájuk (MiNORSKY 1958. 110). A șaqāliba egyrészt jelölhette magukat a szlávokat, de vonatkozhatott általában az erdőlakó népekre, így a szlávokra, volgai bulgárokra, finn-ugor nyelvü népekre is. 
A burtászokkal kapcsolatban Lewicki Szmirnovra és Minorskyra hivatkozik. Szerinte a mordvinok lakják azt a területet, amelyet a burtászok területének határoztak meg más kutatók. A mordvinok már Iordanesnál megjelennek. Sokan iráni nyelvü népcsoportnak tartják őket, vagyis szkíta és szarmata eredetűnek. Lewicki szerint egy ${ }^{\star}$ purtas (iráni) szó, ez a szó megvan az avesztai nyelvben, megvan az oszétben furt, fyrt alakban. Felbukkan Szarmata személynevekbenis, például: Ruhs-as, Chartasis ${ }^{*} k a r t$-as 'ászok kardja' (népnév), ezek analógiájára, az as-fia, as-fiai etimológiát tart elképzelhetőnek (LEWICKI 1965. 7-12.; LEwiCKi 1977. 69-70.). Harmatta János szerint is iráni nyelvű népcsoport volt a burtászoké. Az alán törzsszövetség felbomlása után írja Harmatta - az alán törzsek különböző török törzsszövetségekbe integrálódtak. Így eltüntek a történeti forrásokból. Majd így folytatja: „A régészeti és a történeti kutatás általában jelentős szerepet tulajdonít az alánoknak, mint etnikumnak, mind pedig anyagi kultúrájuk bizonyos elmeinek továbbélése tekintetében.” (HARмATTA 1975. 256.) Több területen számolhatunk alán továbbéléssel. Ami igazán lényeges, az a burtász névben (esetleg) felbukkanó ász népnév, ami az alánokra utal. ${ }^{18}$ Ezt bővebben ki is fejti: „A burtās névnek két ortográfiai hagyománya van az arab-perzsa földrajzi irodalomban: brt's és $b r d$ 's, illetve $b r$ 'd’s. Ezek alapján a Burtās, Burdās alakok mellett Buratāsszal, vagy Buradāsszal is számolhatunk, amely később a fennmaradt helynevek tanúsága szerint Burtāsszá vonódott össze. Így a név első elemében egy alán Buratä, illetve Boräta alakot láthatunk, amelyhez az ās népnév járult. A Boräta név jól ismert név az oszétek mondai hagyományában, mint a nartok egyik nemzetsége. Kézenfekvő arra gondolni, hogy e hagyományban a Boratāsok történeti emléke őrződött meg. Így a burtasokban nagy valószínűséggel egy jelentős alán csoportot láthatunk, amely sajátos etnikai arculatát legalábbis a X. századig megőrizte.” (HARMATTA 1975. 260-261.).

Golden egyik munkájában azzal kezdi, hogy a burtászok egy uráli nyelvű nép, amely a volgai bolgároktól délre és kazár központi területektől északra élnek. Az 1970-es évek eredményei arra mutatnak - noha nem mindenki fogadja el -, hogy a burtászok a volgai finn mordvinok ősei. Továbbiakban a burtász fejezetében Vasil'ev nézetét taglalja. Vasil'ev megállapítja, hogy a burtászok egy külön etnikai csoportosulást alkottak, és hogy nem szabad a mordvá-val összetéveszteni. A muszlim források nyelvüket nem tudják besorolni, ami szintén arra utalhat, hogy az általuk ismeretlen finnugor nyelvcsaládba tartozhattak, véli Vasil’ev, és nyomán Golden. Továbbá a burtász kapcsolata a meščer-magyar/možar-mišär-rel sem biztos. Vagyis nincs egyértelmü bizonyíték arra, hogy a burtászok ugor nyelvet beszéltek volna. Végeredményként megállapítja, hogy a burtászok ugyan félnomádok voltak, ami a magyarokra is jellemzö, de a burtászokat nem rokoníthatjuk a finnugor nyelvü magyarokkal, vagyis egy ilyen, esetlegesen felmerülö tézis kétséges, és újabb forrásadatok hiányában megalapozatlan. Lényegében nem foglal állást a kérdésben (GOLDEN 1980. 88-90.).

Róna-Tas egy tanulmányában arról értekezik, hogy a csuvas nyelvben meglévő purta szó, amelynek jelentése 'fejsze, bárd', biztosan iráni eredetű. Továbbá azt írja, hogy ennek a szónak a megfelelöje, az oszétban faeraet, ami Abajev szerint ó perzsa jövevényszó. A szó jelen van a szír nyelvben és a votjákban is, mint purt 'kés', azonban fonetikai és szemantikai okok miatt, ez a szó független a csuvas szótól. Lehet, hogy ez a szó közvetlenül alán eredetű, ugyanis kronológiai okokból kizárható, hogy a szó közvetlenül az óperzsából származzon. Ezért a következő levezetést ajánlja Róna-Tas: óperzsa para $\delta u>$ alán paratu $>$ oszét faraet > óbolgár baratu > csuvas

18 Az alán és ász népnevekről újabban lásd FEJős 2001. 
purtă (RónA-TAs 1982. 154.). Ez a nyelvészeti levezetés azért olyan fontos számunkra, mert ez közvetlenül kapcsolódik témánkhoz, hiszen a burtász szónak elfogadható etimológiáját adja.

A következő vélemény megfogalmazója G. E. Afanas’ev, aki alapvetően régészeti szemszögből közelíti meg a burtász problematikát. Szerinte a József kazár kagán levelében említett Arisu a mordvinokat jelöli, míg a burtászokat egészen más névvel illeti a forrás, de arra sajnos nem térki Afanas'ev, hogy mi is lenne ez a másik elnevezés. Ezenkívül megállapítja, hogy a burtász népnevet kétféleképpen jegyzik le a források. Ha a burt/furt-ās alakban szerepel a népnév, akkor az Északkaukázusi alánokra utal. Pontosabban azokra az alán („Assian”) törzsekre gondol, amelyek a 8. század közepén vándoroltak a Don középső folyásánál levő medencébe. Összességében tehát Afanas'ev amelett foglal állást, hogy a burtászokat az alánok egy csoportjával lehet azonosítani (AfANAs'ev 1987. 198-199.). Zimonyi István a Korai magyar történet (9-14. század) címü kötetben megjelent szócikkében tulajdonképpen összefoglalja annak megjelenéséig a burtászokkal kapcsolatos különböző elméleteket. Leírja, hogy a burtászok a Volga vidékén előforduló nép, akiknek neve először a 10. századi muszlim forrásokban szerepel. A Dzsajháni-hagyomány alapján megállapítható, hogy a burtászok a kazárok és a volgai bolgárok közötti területen kazár függőségben éltek. A középkori orosz források is említik őket, és a Volga-vidék helyneveiben is megőrződött a népnév. A burtász és mordva népnév egyeztetése következtében, elterjedt az a nézet, miszerint a burtászok a mordvinok elődei. Más álláspont szerint a burtász név összetett alak, és az első tag a furd 'folyó' jelentésű alán szó, míg a második tag, az as, ami egy népnév, az alánok neve. A szó etimológiája 'folyami jászok', ami azt jelentené, hogy nevük alapján iráni nyelvet beszélhettek (Zimony I 1994. 134-135.).

Róna-Tas András újabb munkájában tükröződő véleményét szintén érdemes behatóbban ismertetni, ugyanis azt írja, hogy az Urál és a Volga között élt egy er nevű nép. E nép mai neve ar, mert a tatárok és csuvasok jelenleg így hívják az udmurtokat. Van is ilyen helynév Kazánytól északnyugatra, de ezt a népnevet megőrizték régi források is, például al-Isztahri, finnugor nyelvű népek lakhelyére lokalizálták területüket. ${ }^{19}$ Ebből Róna-Tas, ugor típusú finnugor nyelvet beszélő népnek gondolja őket. Ennek kapcsán mindjárt felvetődik az as-ar név és a két nép kapcsolata, amely egészen új megoldásokhoz vezetne, azonban Róna-Tas ezt a vonalat nem viszi tovább (RónA-TAs 1997. 235.). Róna-Tas a magyar név kialakulásával kapcsolatban közvetve ismét érinti a burtász kérdést. Azt írja, hogy a török nyelvekben szókezdő helyzetben csak akkor volt m-hang, ha utána egy orrhangú, vagyis nazális mássalhangzó következett (RónA-TAs 1997. 229.). Ez azért fontos, mert a bur冈ās/burdās-merdász összevetésénél teljesen egyértelművé válik, hogy egyiket a másiknak nem lehet megfeleltetni. Ugyanis ha ezt a logikát követjük, és azt feltételezzük, hogy a burtászok török nyelvüek voltak, akkor nevük eredeti alakjaként szóba sem jöhet a merdász/mordans/mordvin népnévi forma. Mivel a török nyelvekben csak idegen eredetủ szavak esetében jelenik meg az $m$ - szókezdő helyzetben, illetve jóval későbbi (jövevény) szavakban a török nyelveket illetően. Másrészt, ha nem török nyelvü népességet feltételezünk, és a merdász/mordans alakot tekintjük eredetinek, akkor pedig az a teljességgel érthetetlen, hogy az arab és perzsa nyelvű utazók miért $-b$ szókezdő hanggal írják le a nevet, hiszen a szókezdő $m$ - megjelenik mindkét nyelvben.

Hansgerd Göckenjan kiváló német kutató kiáll a burtász-mordvin rokonság mellett. ${ }^{20}$ Az első pontban megfogalmazza, hogy: „nyelvtörténetileg mindkét név egymással teljesen

19 Lásd: Kмоsкó 2000. 29-32.

${ }^{20}$ Cikkében bőven foglalkozik a Riccardus-féle jelentéssel és Rubruk leírásával (GöcKENJAN 1997. 93-118.). 
összhangba hozható" (GöcKENJAN 1997. 106.). Ez azonban följebb már tárgyalt nyelvtani nehézségek miatt kizárható. Ezen kívül, leírja, hogy a Riccardus-féle jelentésben található Veda alakból levezethető a merdász, vagyis a mordvin népnév. A mordvinokról megjegyzi még azt is, hogy míg egy részük muszlim lett, többségük megtartotta ősei animista hitét (GöcKENJAN 1997. 103-107.). Ezen elmélet nem tartható, a levezetés pedig „több sebből vérzik”, mert nem csak a veda-merdász azonosítás, hanem a merdász-burtász összekapcsolás sem helytálló. Ráadásul a följebb már leírt önelnevezési probléma is súlyosbítja a helyzetet, (ami már korábban is felhívta a figyelmünket arra, hogy a burtászok nevét nem a mordvin névvel kell összevetni).

József kazár kagán levelében szereplő népek közül a burtász, bulgár és a szuvár könnyen azonosítható. Az arisu a mordvinok elnevezése, amit az erzä névvel, azaz a mordvinok egyik csoportjának önelnevezésével lehet összekötni (AgYAGÁsı 1999. 87.). De Agyagási nem vette figyelembe Julianus útleírását, amelyben szerepel egy Bundaz nevü város. Ugyanakkor nyilvánvaló, hogy a kazár kagán szisztematikusan azokkal a népekkel kezdte meg a felsorolást, akiknek városuk van. ${ }^{21}$ Ráadásul a kazár kagán az arisukat és a burtászokat megkülönbözteti. Agyagási viszont feltételezi, hogy az erzák azonosak a burtászokkal.

W. Barthold a burtászokról a következöket foglalja össze. Olyan pogány törzs voltak, akik a Volga folyó völgyében éltek a bolgárok és a kazárok szomszédságában. A források alapján azt írja, hogy a forrás azon kitétele, hogy: „b folyója” a Volgát jelenti. Marquart meghatározása szerint ez a Szamara folyó. Az arab és a perzsa források sehol nem említenek olyat, hogy a burtászok között lettek volna muszlim hitüek, mint ahogyan a kazárokról és a volgai bolgárokról megemlítik. Barthold al-Yāqūtra hivatkozva azt írja, hogy a burtászok és az iszlám világ között élénk kereskedelmi kapcsolat volt, aminek egyik legfontosabb árucikke a szőrme volt. Valamint ő is a burtász-mordvin azonosság mellett foglal állást. Kiemeli, hogy a burtászok a Volga jobb partja mentén éltek, ahol finnugor és szláv népekkel voltak határosak. Később a mongol támadások hatására északabbra húzódtak (W. BARTHOLD: Burțās. In: EI² I. 1337-1338).

E fejezetben az utolsó fontos kérdés, hogy a burtász név önelnevezés-e. A kérdés szinte eldönthetetlen, de itt is segítenek a források. A tárgyalt népet, szinte csak burtász elnevezéssel illették. Ebböl arra következtethetünk, hogy ez volt az önelnevezésük. Ezt pedig az is erősíti, hogy a burtászokat a közvetlen szomszédaik is ezen a néven említik. ${ }^{22}$

\section{A burtászok nyelve}

A burtászok nyelvének meghatározása rendkívül fontos, ugyanis korántsem biztos, hogy egy nyelvet beszéltek. A források erre vonatkozóan a következőket közlik:

- al-Isztahri: „A kazár nyelv sem nem török, sem nem perzsa, sem nem tagja a nemzetek más nyelvágának" (Кмоsкó 2000. 29.).

${ }^{21}$ A folyó mellett sok nép falvakban és részben nyílt, részben megerősített városokban lakik. Ezek neve: Burtasz (Burts), Bulgar (bulgr), Szuvar (Su'r), Ariszu ('rysu), Cermisz (Crmys), Venentit (Vnntyt), Szuvar (Suur), Clavijun (Cluyun), mindegyik igen nagy, számtalan sokan vannak, és nekem fizetnek adót)" (SHLomoKomoróczy 2003. 100.; KoHN 1990². 39).

22 Idevágó párhuzamként említhetjük azt a megfigyelésen alapuló tényt, hogy egy nép közvetlen szomszédai szinte mindig az adott nép önelnevezését veszik át, hosszabb-rövidebb idő után. Míg a velük közvetlenül nem határos népek, más névvel is illethetik őket, ami rendszerint a közvetítő nyelven keresztül való kölcsönzés eredménye. 
„Bulgār nyelve olyan, mint a kazárok nyelve; burțās nyelve azonban más, hasonlóan a rūs nyelve is más, mint a kazár s a burțās" (Кмоsкó 2000. 31.).

- Ibn Hauqál: „A bulgār nyelve olyan, mint a kazárok nyelve; bur冈ās nyelve azonban más; hasonlóképpen a rūs nyelve is más, mint a kazárok és bur®ās nyelve” (KMOsKó 2000. 80.).

Ezekből a híradásokból azt szűrhetjük le, hogy a burtászok nyelve nem tartozott a török, sem pedig a szláv nyelvek közé. Úgy tünik, a burtászok nyelvi hovatartozását a muszlim forrásokból nem lehet megadni. A burtászok megítélésénél a jól tájékozott és kortárs muszlim források az alapvetők, mégis kellő kritikával kell kezelni őket. Ugyanis tévedhetnek, elfogultak lehetnek, hamis információt kaphattak, félreérthették egymást. Ugyanakkor a forrásokból más következtetést is levonhatunk. Ha feltesszük, hogy a kazárok nyelve azért ismeretlen al-Isztahri számára, mert az arabok és a perzsák csak a köztörök típusú nyelveket tartották töröknek, és számukra a kazár és a volgai bolgár nyelv nem hangzott törökként, így aztán ismeretlen nyelvnek írták le. Ez megmagyarázná al-Isztahri szöveghelyét, viszont fölvet egy másik problémát. Mégpedig azt, hogy ez esetben szerzőnk miért nem írta egyszerüen azt, hogy a burtászok török nyelvűek. Ami viszont a forrásadatok alapján kizárható az-az, hogy a burtászok szláv nyelvűek lettek volna. Göckenjan hasonló gondolatmenet után jut el oda, hogy a burtászok finnugor nyelvüek voltak. Ezt harmadik tételében (amely a burtász-mordvin azonosságot levezető elméletének része), úgy fogalmazza meg: „A földrajzíró Ișțahrí igazolja, hogy a burtászok nyelve nem tartozik a török nyelvekhez" (GöCKENJAN 1997. 106.). Azonban azt sem írja, hogy nyelvük finnugor eredetü vagy ahhoz hasonló lenne.

Összefoglalásként elmondható, hogy a muszlim források részletekben gazdag, viszonylag pontos híradásokat nyújtanak a burtászokról. Ezek az írásos emlékek megbízható információkat adnak, az életmódbeli sajátosságaikra (kereskedelem, állattartás, házassági szokások), lokalizációjukra, és tájékoztatnak bennünk arról, hogy a kazárok katonai segédnépei voltak, bár nem szabad elfelednünk, hogy ezek a leírások a muszlim utazók szemléletén keresztül mutatják be az adott dolgokat. Mivel a burtászoktól nem maradt ránk semmiféle írásos emlék, így teljes bizonyossággal nem tudjuk eldönteni, hogy milyen nyelven beszéltek. Népnevük alapján lehetnek eredetüek meghatározása meglehetősen kétséges, a finnugor eredetüket az elmélet képviselöi nagyon bizonytalan népnév-etimológiákkal igyekeznek alátámasztani. A leghangsúlyosabb az iráni eredet a népnevüket illetően, ugyanis a legtöbb és egyben legjobb etimológia erre a lehetöségre épül. Ugyanakkor közismert tény, hogy népnévböl nem lehet meghatározni egy nép nyelvét és etnikai hovatartozását. Továbbá problémás a régészeti adatokból kiindulva következtetni az adott nép nyelvére. Hasonló okok miatt a katonai létszámukból sem lehet kikövetkeztetni a népesség nagyságára. Az írott források alapján komplex gazdálkodási rendszerben éltek, vagyis földművelés és a nagyállattartás egyaránt jelen volt a burtászoknál. Az is biztos, hogy a szállásterületük a Volgától nyugatra volt, és akár a Donig is elérhetett. Tény továbbá az, hogy a burtászok az erdős sztyeppén éltek. Északon területük benyúlhatott az erdővidékre, míg délen a sztyepp egy részére is kiterjedhetett fennhatóságuk. Gazdálkodásuk ezeknek a kondícióknak megfelelöen alakult. A muszlim források mellett a latin, héber és orosz nyelvű források felhasználása alapján egyértelmünek látszik, hogy a burtász nép nem azonos a mordvinokkal. Ennek igazolása során a források mellett segítségemre volt a mordvinok önelnevezése. Tehát a burtász egy önálló nép volt a Közép-Volga-Don vidéken, amely délről a kazárokkal, északon pedig a volgai bolgárokkal volt határos. A burtászok a 10. század végéig kazár függőségben éltek, majd a volgai bolgárok, és később a ruszok fennhatósága alá kerültek. Az 1230-as évek mongol támadás nyomán mongol alattvalók lesznek, majd fokozatosan eltünnek a forrásokból. 


\section{FELHASZNÁLT IRODALOM}

AfANAS'Ev G. E. 1987: Население лесостепной зоны Бассейна среднегоДона в 8-10 в в. Археологические открытия на новостройкках. Moskva. 198-199.

AgYAGásı K. 1999: A cseremisz etnogenezis rekonstrukciójához. In Ujváry Z. (szerk.): Ünnepi kötet Szabó László tiszteletére. Debrecen. 85-94.

$\mathrm{EI}^{2}=$ The Encyclopaedia of Islam. CD-ROM Edition v. 1.0. Brill NV. Leiden, 1991.

Fejős BARbara 2001: Az alánok és a kereszténység, In Felföldi Sz. - Sinkovics B. (szerk.): Nomád népvándorlások magyar honfoglalás. MÖK 15. Budapest. 36-44.

Golden, P. B. 1980: Khazar Studies. I. Budapest.

Göckenjan, H. 1987: Kelet-Európa népei a 13. századi magyar domonkosok útleírásaiban. Aetas. Történettudományi folyóirat 2-3, Szerk.: Koszta László, 93-119.

Göckenjan, H. 2001: Felderítők és kémek. Tanulmány a lovasnomád hadviselés stratégiájáról és taktikájáról. In Felföldi Sz. - Sinkovics B. (szerk.): Nomád népvándorlások magyar honfoglalás, MŐK 15. Budapest. 57-66.

GYöRFFY GY. 1948: Krónikáink és a magyar östörténet. Budapest.

GYöRFFY Gy. 1986: Julianus barátés a napkelet fölfedezése. Vál., a bev. írta és jegyzetekkel ellátta Györffy Gy. Ford. Györffy Gy. és Gy. Ruitz I. Budapest.

Harmatta J. 1975: Az alánok Kelet-Európában a korai középkorban. Antik Tanulmányok 1975. 22. évf. 256-261.

Igló E. - Misley P. 1979: Régi orosz széppróza. Budapest. 83-84.

KoHN S. 1990²: Héber kutforrásokés adatok Magyarország történetéhez. Budapest, 1881. (reprint 1990).

Кмозко́ M. 1997: Mohamedán írók a steppe népeiről. Földrajzi irodalom. Szerk: Zimonyi I. MŐK 10. Budapest.

Kмоsкó M. 2000: Mohamedán írók a steppe népeiről. Földrajzi irodalom. Szerk: Zimonyi I. MŐK 13. Budapest.

LEWICKI, T. 1965: Ze studiów nad źródłami arabskimi III. Ètudes sur les sources arabes III. Slavia Antiqua 1965. 12.1-33.

Lewicki, T. 1977: Źródła arabskie do dziejów słowiańszczyzny. II/2. Wrocław-Warszawa-KrakówGdansk

Minorsky, V. 1937: 囚udūd al- ${ }^{c} \bar{A} l a m$. The Regions of the World. A Persian Geography 372 A.H. 982 A.D. London.

Minorsky, V. 1958: A History of Sharwān and Darband in the $10^{\text {th }}-11^{\text {th }}$ centuries. Cambridge.

RónA-TAs, A. 1982: The Periodisation and Sources of Chuvash Word Yumśă „Sorcerer”. In Chuvash Studies, Szeged, 113-171.

RónA-TAs A. 1997²: A honfoglaló magyar nép. Budapest.

Shlomo, J. Spitzer - Komoróczy G. 2003: Héber kútforrások Magyarország és a magyarországi zsidóság történetéhez a kezdetektöl 1686-ig. Budapest.

Togan, Z. V. 1939: Ibn Fa囚lān Reisebiricht. Leipzig.

Zahoder T.H.: Каспийский свод сведену Заходер T.Н.: Каспийский свод сведену Заходер о восточной Европе. I, Moskva.

ZıмonYi I. 1994: Burtaszok. In Kristó Gy. (főszerk.) - Engel P. - Makk F. (szerk.): Korai magyar történeti lexikon (9-14. század). Budapest. 134-135.

Zsirai M. 1937: Finnugor rokonságunk. [Reprint 1994, Budapest] Budapest. 